\title{
Circulação, afetos e migração: notas para uma análise antropológica de mulheres trans em terras indígenas da Paraíba'
}

Verônica Alcântara Guerra²

Resumo: Este artigo sintetiza pesquisas realizadas no Litoral Norte da Paraíba entre os anos de 2009 e 2014 e percorre os caminhos traçados por três mulheres trans que nasceram em aldeias indígenas da etnia Potiguara. No texto procuro apresentar e descrever os processos e movimentos relativos às sexualidades, sociabilidade e mobilidades local e transnacional realizadas por elas e, sinalizando como valores da "indianidade" são postos como diferenciação no mercado do sexo. Em tais espaços o corpo é experimentado como performance e como materialização do gênero que percorre e constitui aldeias, cidades pequenas da região e Europa.

Palavras-chave: Corpo, Sexualidade, Prostituição, Migração

Circulation, affect and migration: notes towards an anthropological analysis of transgender women in ethnic territories of Paraiba

Abstract: This paper summarize researches I've conducted in Nothern Coast of Paraiba between 2009 and 2014 and traces the paths of three transgender women born in Potiguara ethnic territory. In the text I sought to present and describe the

\footnotetext{
1 Financiamento: CNPq/CAPES.

2 Programa de Pós-Graduação em Antropologia da Universidade Federal de Pernambuco (PPGA - UFPE) - Recife - Brasil - well_guerra@yahoo.com.br
} 
process and movements related to sexualities, sociability and local and international mobilities carried out by them, arguing how ideas about indianity are posited as a differentiation in the sex market. In such spaces the body is experienced as performance and as materialization of gender that runs through and constitute villages, small towns in the region and Europe.

Keyowrds: Body, sexuality, prostitution, migration

\section{Introdução as narrativas históricas e transcoloniais}

Em 1501, Américo Vespúcio escreve ao Rei de Portugal sobre um grupo de mulheres nuas e de pele vermelha. Elas, ao perceberem que havia caravelas com homens brancos atracados próximo à praia, começaram a dançar e cantar de forma sedutora para os embarcados. Eles não resistiram a tais encantos, deixaram os barcos e se dirigiram até a praia, ao chegar em terra firme, foram surpreendidos por homens que estavam escondidos atrás das árvores, estes empunhavam arcos e flechas. Os homens brancos foram atraídos para uma armadilha, cuja isca era os corpos repletos de libido e perigo das fêmeas do novo mundo. Após a captura, em um ritual antropofágico, os marinheiros portugueses foram devorados pelos Potiguara.

Esta cena colonial poderia ter acontecido em qualquer costa do litoral do novo mundo, mas reza a lenda que ocorreu na Baía da Traição, uma terra repleta de histórias de infidelidade e conquista que remonta colonização europeia. Até os dias de hoje, ao passear pela costa da cidade em direção a Aldeia São Francisco, considerada um lugar sagrado e materno para os Potiguara, é possível observar o passado bélico na Aldeia do Forte, que ainda preserva três grandes canhões, os menores e mais leves foram movidos para compor a decoração da casa de alguns indígenas. Em um projeto de conquista e naturalização da dominação de gênero, não à toa a terra tornou-se mãe. Por essa razão, "quando os homens europeus atravessam os perigos limiares de seus mundos conhecidos, ritualisticamente tornavam femininas as fronteiras e os limites" (McClintock, 2010: 47). As mulheres, de maneira histórica, foram usadas como ferramentas para delimitar as fronteiras do império, a exemplo das matas e terras virgens, ninfas e sereias que seduziam e atraiam os marinheiros distraídos para o fundo do mar.

A dominação colonial passa pela Baía da Traição, uma cidade com pouco mais de 9 mil habitantes, poderia ser considerada facilmente o "cu do mundo", um lugar onde supostamente o projeto de modernidade brasileira não se efetivou, no entanto, na Baía da Traição "tudo é centro", como disse uma das minhas 
interlocutoras. Posto isso, pergunto-me o que seria margens e fronteiras descentradas? O que entendemos por efetividade de um projeto de modernidade? Quais são as características das localidades consideradas afastadas dos centros geoculturais? Se na Baía da Traição tudo é centro, como me fez crer uma jovem travesti ${ }^{3}$, não cabe aqui escrever sobre suas carreiras por meio de uma perspectiva de marginalidade e, como bem argumenta Mary Douglas (1976: 149) "todas as margens são perigosas. Se são empurradas desta ou daquela maneira, a forma da experiência fundamental é alterada. Qualquer estrutura de ideias é vulnerável em suas margens".

O paradoxo entre desejo e repúdio que acompanha as mulheres trans, centra-se tanto na ideia do feminino que transformou o corpo nascido masculino por meio dos desejos sexuais e de gênero, quanto pela concepção histórica empregada ao corpo de pessoas não brancas/europeias. Ao escrever sobre "A situação da terra - genealogias do imperialismo", Anne McClintock (2010) argumenta que os considerados "pornotrópicos" foram criados pelos europeus a fim de sexualizar os corpos de homens e mulheres não brancos, não obstante, "dentro dessa tradição pornotrópica, as mulheres figuravam como a epítome da aberração e do excesso sexuais. $\mathrm{O}$ folclore as via, ainda mais que aos homens, como dadas a uma lascívia tão promíscua que beirava o bestial" (McClintock, 2010: 45).

A intervenção europeia nas Américas, datada dos anos 1500, mudou para sempre o relacionamento das pessoas entre si e destas com o mundo. Assim, volto a perguntar em que consiste o projeto de modernidade brasileira e o que é centro? Se considerarmos uma posição evolucionista, podemos dizer que no Litoral Norte da Paraíba teve início um audacioso projeto de modernidade, por meio da colonização europeia, milhares de vidas dos povos nativos foram dizimadas em uma falsa concepção de ocupação das "terras vazias" (McClintock, 2010) e catecismo como ferramenta civilizatória.

Marcada pelo trabalho escravo nas prósperas lavouras de cana de açúcar e extração dos bens naturais, esta região atraiu a atenção dos mais poderosos, sendo considerada um centro econômico. No início do Século XX, instalou-se na região a mais moderna fábrica de tecidos do país, a Companhia de Tecidos Rio Tinto (CTRT), dos irmãos Lundgren, que deu origem a projetada cidade

3 Travesti é uma nativa e usualmente elas se chamam de mulher, bicha, viado, entre outras nomenclaturas. Por uma escolha teórica, opto por usa mulher trans ou trans, visto que este é um termo acionado na escrita acadêmica. 
fabril, Rio Tinto $(\mathrm{PB})^{4}$, em seu auge chegou a empregar mais de 20 mil pessoas. Assim, o Litoral Norte possui uma "glória industrial passada" e nos dias atuais, além de perpetuar a tradição da lavoura de cana de açúcar e possuir grandes usinas, é reconhecida como um centro universitário com cursos superiores na Universidade Federal da Paraíba.

Há poucos quilômetros das terras indígenas, está localizada a cidade de Mamanguape-PB, atravessada pela BR 101, liga as capitais João Pessoa (PB) e Natal (RN). No dia 1 de abril de 2009, acompanhada de Silvana Nascimento (professora do campus IV, UFPB) e Jefthe Sarmento (aluno de Antropologia-UFPB), fiz minha primeira incursão, não apenas ao campo de pesquisa da antropologia, mas em um universo de reflexões sobre as mulheres trans da região. Passei a conhecer suas vidas e a compreender melhor os locais de maneira geo-histórica e política, assim, foi possível perceber não apenas as formações e transformações de corpos e histórias, mas a formação espacial do Litoral Norte da Paraíba (Guerra, 2012). Estas mulheres trans cruzavam os asfaltados e chão batido, espaços urbanos e indígenas para desempenhar uma performance que trazia em si aspectos intimamente ligados à abjeção e ao desejo (Pelúcio, 2009).

Nesta região, mulheres trans, indígenas ou não, têm seus espaços de trabalho, residências e casas de parentes distribuídos por espaços onde as características: rural, urbano e indígena são atravessados. Mesmo que a origem e residência de algumas seja em território indígena, elas transitam entre os variados espaços. Karla, no momento da pesquisa, trabalhava no mercado do sexo durante a semana e aos fins de semana passava na casa dos pais, ocasiões que ela considerava prazerosa, ir para aldeia era para ela uma atividade afetiva e de lazer. Neste aspecto, ela se afasta de Kelly, sua prima. Ao completar a maior idade, migrou para Europa, onde residiu por 3 anos. A aldeia é considerada por ela um lugar sem oportunidades de trabalho e, sempre que possível sai para tentar trabalhar e morar nas maiores cidades da região. Ramona Pink tem mais de 30 anos e sempre morou na aldeia, ela é responsável pela organização da casa que mora com o pai e o irmão, sempre que pode é diarista em casas de famílias ou trabalha na roça em épocas de colheita e plantio.

Ao pensar sobre a composição dos espaços da região no Litoral Norte (LN), Silvana Nascimento (2008:19) argumenta que é "justamente na articulação entre contextos urbanos, rurais, indígenas e marítimos que se revela a

\footnotetext{
4 Mais informação ler a dissertação Os Potiguara da Baía da Traição e Monte-Mór: história, etnicidade e cultura, de Estêvão Martins Palitot (2009).

5 Trecho da música "filhos da cidade fabril". Banda Transagem.
} 
especificidade do Litoral Norte da Paraíba, sem deixar de ser cidade e apresentar estilos de vida urbana”. Desse modo, a proximidade das fronteiras aldeia/ cidade/zona rural, favorecem as relações dinâmicas entre a cidade e o campo. As mulheres trans trafegam nesses espaços em busca de lazer, festas e trabalho. São locais nos quais se configuram as relações de sociabilidade e lazer, trocam informações sobre roupas, maquiagens e melhor lugar para trabalhar no momento. É também em ambientes festivos e de trabalho que elas encontram seus "ocós", possíveis namorados ou casos, flertam, dançam e também trabalham, caso tenham oportunidade.

No que diz respeito a metodologia de pesquisa aqui empregada, deve-se frisar que as narrativas contidas nesse artigo são frutos de entrevistas e pesquisa de campo, cujo objetivo era compreender a conjugação de atos negociados pelas trans indígenas para a trans/formação de seus corpos e vivência da sexualidade, assunto pouco explorado por antropólogos em territórios indígenas, no qual os usos dados ao corpo delimita a potência do gênero. Assim, as histórias de Karla, Kelly e Ramona Pink 7 estão atravessadas, sobretudo, por um saber colonial sobre seus corpos, gênero e sexualidade que vai do nascimento e vivência na aldeia às ruas italianas.

\section{Cruzamentos: vidas que pesam}

Este artigo tem como objetivo analisar vivências de três mulheres trans autodeclaradas indígenas Potiguara e os usos da categoria étnica como ferramenta de respeito e prestígio dentro da aldeia, de exotização e fetiche durante o trabalho no mercado do sexo europeu. Diante das dinâmicas colocadas com base nos fluxos e nas fronteiras, pensar este artigo como uma produção centrada em um determinado lugar fixo e imutável consistiria, sem dúvida, num engano. Assim, como nossas colaboradoras, o próprio texto é uma mobilidade, não apenas dentro das terras indígenas, mas entre a aldeia e a cidade e, destas com a Europa, no qual podemos perceber que o imaginário criado pelos imperialistas sobre os povos nativos foi usado séculos depois como ferramenta de distinção e sedução dos europeus, em território italiano.

Entre as trans que afirmavam pertencer a etnia Potiguara, Karla, medindo por volta de 1,60 de altura, cabelos na linha dos ombros, pele morena e pernas torneadas disse ser a primeira homossexual a se transformar em uma mulher trans na região do LN, no entanto, ela deixa transparecer um

\footnotetext{
$6 \quad$ Nome usado para se referir aos homens.

7 Nomes sociais escolhidos por elas mesmas.
} 
intenso jogo de fluidez no que diz respeito as identificações de gênero. Para ela, na medida que for envelhecendo deixará de ser trans, pois considera feio "travesti velho". Em outro aspecto, ela considera o cabelo um limiar entre voltar a ser homem ou estar mulher. Durante nossas longas conversas, ela expressava seus desejos sexuais por mulheres cis, mas afirmava que preferia penetrar os homens e passava muito tempo do seu dia fazendo a manutenção do seu "corpo de mulher". Ela nunca "aquendava" a "neca", dizia ter o pênis grande e, sempre usava roupas sumárias que evidenciavam, com orgulho, a protuberância dos genitais. Este tipo de comportamento faz crer que Karla não emoldurou suas identificações de gênero e sexualidade nas categorias "travestis" ou 'homossexual". Nesse sentido, para Beatriz Pre-

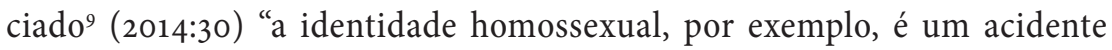
sistemático produzido pela maquinaria heterossexual, e estigmatizada pelo antinatural, anormal e abjeta em benefício da estabilidade das práticas de produção natural". Ao negociar suas posições morais e constituição da estética da existência, Karla evidenciou as falhas nos modelos reais de masculino e feminino.

O gênero, enquanto materialidade dos corpos (Preciado, 2014) na experiência de Karla, teve início no ventre materno. Nascida na aldeia Tramatáia por intermédio de uma parteira, ela conta que estava "laçada" e, de acordo como a parteira, a qual era obrigada a considerar "madrinha”, a criança não havia trazido uma boa sina. O destino do corpo de Karla já estava selado. Advertira pela parteira, sua mãe sabia que o bebê, mesmo com a genitália masculina tinha o espírito de menina. Na tentativa de burlar as escritas do destino, sua mãe a batizou com um nome de santo, José.

Para os nordestinos, em especial, quando uma criança nasce com o cordão umbilical laçado ao pescoço, entende-se que ela correu um grande risco de morte ou, segundo Karla “trazer sinas péssimas!”. A interpretação do nascimento feito pela parteira, deixou a mãe de sobreaviso. $\mathrm{O}$ nome de santo não foi suficiente, ela já sabia que o filho se tornaria uma "menina", por essa razão, o corpo afeminado de Karla não causou surpresa ou rejeição no âmbito familiar, mas tampouco era considerado uma dádiva. Seja como for, a sexualidade dissidente de Karla - na falta de um termo melhor - anunciada desde o nascimento, não estava ausente dos aspectos negativos, portanto, a forma de agir no mundo era considerada "péssima".

8 Truque usado para diminuir o volume do pênis.

9 Atualmente Preciado assina como Paul e vive no masculino. 
Não obstante, imbuído pelo ponto de vista do saber local, um leitor desatento e fascinado pela hermenêutica nativa sobre a aparência e a sexualidade de Karla, julgaria ser esta uma maneira singular de compreender o gênero em terras distantes dos considerados centros de desenvolvimento cultural brasileiro, mas neste caso, o que observamos é a colonização formatando os modos de existir dos povos nativos. "Madrinha", "nome de santo" e "José" são insígnias deixadas e fortalecidas pelos jesuítas e catolicismo, no qual não é bom o menino ter um destino de menina. No entanto, é importante frisar que aldeia é para Karla um lugar seguro, pois pertence ao um grupo familiar considerado "forte" e "ninguém mexe" com ela. É para aldeia que volta todos os finais de semana, este é também tido como um lugar de lazer.

Assim, as práticas consideradas abjetas afetam o que há de mais íntimo das relações afetivas, o sexo. $\mathrm{O}$ paradoxo acompanha o abjeto, pois ao passo que excita, também existe um movimento que repele. Neste aspecto, considero importante relembrar a primeira conversa que tive com Karla, na cidade de Mamanguape, no fim de 2009. Passou-se meses até que ela se sentisse confiante para conversar comigo, pois me considerava uma "racha falsa". Para ela todas as mulheres eram falsas, pois riam das travestis pelas costas e, como formas de proteção, mantinha-se distante de mim. No entanto, havia me tornado próxima das outras trans que dividiam a casa com ela e as minhas visitas eram frequentes.

Certa tarde, quando conversávamos na sala, Karla aparece com cheiro de banho recém tomado, trajando um short jeans escuro e uma blusa que deixava a barriga à vista. Elogiei seu cheiro e ela sentou em silêncio ao meu lado na cama, que ficava na sala da casa. Ao perguntar sobre o final de semana, pudemos estabelecer uma relação de troca de informações. Perguntas, respostas, silêncios e risos deram o tom para nosso diálogo. As narrativas de Karla são repletas de cenas sexuais, em muitos momentos chega a lembrar as narrativas feita por Fernanda Farias de Albuquerque ao líder das Brigadas Vermelhas em uma prisão italiana. A Princesa fala sobre a sua infância e o seu devir animal aos seis anos, durante as brincadeiras com seu priminho e vizinho.

Eu era a vaca. Genir, o touro, Ivanildo, o bezerro. Short e camisetas despidos com pressa dentro do mato. Longe de todos, era o segredo. Genir mugia e me perseguia. Uma brincadeira de empurrões, pegação e respirações ofegantes. Ele montava a vaca endemoniado em cima de mim. Mexia, feito filhote de bicho trepado na perna do dono. Pinto de menino e esfregação.

10 Nome usado para se referir às mulheres de pouca confiança. 
Ivanildo, o bezerro, priminho desajeitado, enfia o focinho naquele inferno. Umedecia e chupava debaixo da minha barriga. Oh! Ivanildo, procura a teta! (Albuquerque; Jannelli, 1995: 26).

Em outra passagem Fernanda, relata a vontade de ver o "pau" de um homem mais velho e, por essa razão, aproveitou a viagem da mãe viúva para ficar atrás de um arbusto na estrada de terra na zona rural e perguntava aos homens que por ali passavam, se podia ver o "caralho" deles. Entre os transeuntes, vinha um homem bêbado, conhecido da família, com pouco mais de 30 anos, este aceitou a proposta de Fernandinho que consistia em lhe dar bebida, comida e, em troca, mostraria seu pênis "ereto e grande". Arlindo, o bêbado, tentou penetrar o pequenino que ficou apavorado, chorou e se mexia resistente entre as grandes pernas do homem e, só conseguiu fugir pela janela quando alguém bateu na porta da casa.

Voltando para Karla, ela relata que sua primeira relação sexual se deu muito jovem e com um homem mais velho. Diferente de Princesa, que jamais admitiu ter relações sexuais com mulheres, para Karla esta era uma prática desejável. Ela não se sentiu satisfeita com homem, por ficar na dúvida, quis experimentar uma mulher. Karla mantinha relacionamentos afetivos com as meninas da aldeia e com um homem mais velho e casado. De maneira cronológica, ela explica: "comecei ficar primeiro com homem, aí depois de um certo momento comecei a ficar com as meninas... Minha primeira relação eu tive aos quatorze anos com uma mulher".

A relação sexual com o homem mais velho, precedeu as das meninas, no entanto, Karla argumenta que tinha consciência do que estava acontecendo, tinha vontade própria e curiosidade. Em seguida argumenta: "É tanto que eu já experimentei de um tudo: homem, mulher, lésbica... Até três travesti me chupou, já! E uma delas eu penetrei, uma colega minha. Até mesmo com travesti já aconteceu. Mas se for para eu dar minha bunda a um travesti eu não dou de jeito nenhum!' Mesmo sentindo-se livre para manipular a sexualidade, é possível perceber que as experimentações e não-experimentações com o corpo têm os seus parâmetros, experimentar de um tudo encontra seu limite no corpo de outra trans.

O abjeto é tudo que o sujeito procura expurgar para tornar-se social; é também um sintoma do fracasso dessa ambição. Como um compromisso entre "condenação e anseio", a abjeção marca os limites do eu; ao mesmo tempo, ameaça o eu com perigo perpétuo. Desafiando limites sacrossantos, a abjeção testemunha o precário controle da sociedade sobre os aspectos fluidos e não refinados da psique e do corpo (McClintock, 2010: 119). 
Assim, como suas colegas de casa, Karla trabalhava como prostituta no mercado do sexo, como frequência elas mantinham relacionamentos com homens que consideravam seus maridos. Estes homens tinham, necessariamente, que performatizar uma masculinidade imaculada, longe de qualquer suspeita de que eram penetrados pela "esposa" trans. A descoberta de tais atos, podia afetar não apenas a masculinidade, mas também o relacionamento entre eles. Em nome da honra, com frequência, o marido agride a esposa que depusesse contra sua virilidade de macho. Ao falar sobre seu casamento, Karla explica que " $O$ ciúme de um homem com uma travesti é duas vezes mais forte do que entre um homem e uma mulher!" A meu ver, esta explicação parece lhe confortar, pois ao mesmo tempo que destaca o ciúme exagerado, ela evidência sua capacidade de autodefesa. Sobre o relacionamento, ela diz: "Briguei com meu marido, aí ele pensou que podia bater em mim, mas tava muito enganado (...)”.

Karla argumenta que a maioria dos homens procuram as trans, porque elas têm coisas que as mulheres não têm. Seguindo sua lógica: "em todos os sentidos [as trans] são mais carinhosas do que as mulheres (...) o carinho é duas vezes mais que a mulher?". Ela justifica seu argumento usando como exemplo a própria experiência afetiva. Vejamos:

No caso do meu marido... Ele era casado, tinha a família dele... diz ele que nunca tinha ficado com travesti e, aí... aconteceu da gente ficar. Ele foi morar comigo. Conheci ele em uma Quinta-feira e no Sábado ele foi morar comigo. Deixou a mulher dele para ficar comigo, mas assim, se ele quisesse sentir prazer, ele tinha com a mulher dele, no caso, se ele quis ficar comigo é porque ele queria algo diferente. Tanto ele me penetrava, com eu penetrava ele, ficava assim, vivia assim... mas eu comentei isso pra minhas amigas de confiança. (...) [uma delas] começou a chamar ele pelo nome de mulher e, hoje em dia, a gente não pratica mais isso e a relação da gente piorou.

As posições dos corpos nas relações sexuais entre as trans e seus namorados, maridos ou ocós são moralmente relevantes, pois os homens casados ou namorados das trans vêm a si como heterossexuais, portanto, não passivo e, comentários que são penetrados por suas namoradas não é algo aprovado (Pelucio, 2011). Isso ocorre porque os homens preservam a inteligibilidade heterossexual (Perlongher, 2008). Caso a noção de virilidade seja contestada, pode ocorrer atos violentos e homofóbicos contra suas companheiras trans. Neste caso, é possível perceber que a complexidade das relações de gênero está, sobretudo, desenhada no corpo material e ligada à posição que eles ocupam durante o sexo considerado abjeto, ou seja: 
Povos abjetos são aqueles que o imperialismo industrial rejeita, mas que não pode prescindir: escravos, prostitutas, os colonizados, trabalhadores domésticos, loucos, desempregados e etc... Certas zonas limiares se tornam abjetas e são policiadas com vigor: a Casbah árabe, o gueto judeu, a favela irlandesa, o sótão e a cozinha vitorianos, o acampamento dos invasores, o asilo mental, o distrito das luzes vermelhas e o quarto de dormir. Habitando o espaço entre domesticidade e mercado, entre indústria e império, o abjeto retorna para assombrar a modernidade como seu repúdio íntimo e constitutivo: o rejeitado de que não conseguimos libertar-nos (McClintock, 2010: 119).

A abjeção pode ser considerada um estado limiar entre o corpo enquanto matéria e o corpo político (McClintock, 2010). Portanto, a disciplina história dos corpos e o policiamento do quarto de dormir criou um sistemático conjunto explicativo, cuja base é o afeto entre as pessoas. Este sistema de justificação pode ser encontrado nos relacionamentos dos povos nativos e não nativos. Dessa forma, Karla explica que seu marido havia se apaixonado por ela, em nome desse afeto, ele deixou a família e passaram a morar juntos, ainda por amor, ele permitia ser penetrado, mas exclusivamente por ela e nunca antes. A penetração como barganha e prova física de amor, não chegou a convencer Karla, para ela "isso é o homem que tem vontade de dar, mas não procura um homem e vai atrás de uma travesti. Eles procuram uma travesti porque a mulher não tem o que eles querem". Se, "o gênero se parece com o dildo", como faz crer Beatriz Preciado (2014: 29), o amor pode ser considerado um ânus orgástico e penetrável em uma espécie de segredo mal falado. Explica Karla:

(...) às vezes tem gente que me pergunta $\mathrm{e}$ eu minto, mas na verdade não, não tem como! Se você vê um casal, travesti com um homem, pode ter certeza que aquele homem também é... é penetrado pela travesti. Até hoje eu custo a acreditar, só tem uma travestis, que disse que morou mais de dez anos com um homem e que ela nunca penetrou ele, é mentira! A terceira vez que eu fiquei com meu marido eu penetrei ele.

Por outro lado, Don Kullik (2008), na sua pesquisa em Salvador (BA), relata que as travestis não gostam de penetrar os seus namorados, caso aconteça, o companheiro quer de alguma forma segurar o relacionamento que está gasto. Algo também registrado nos trabalhos de Larissa Pelúcio (2011) e Thiago Duque (2009) no Sudeste do Brasil. Entretanto, para Karla as travestis gostam de penetrar seus companheiros, no entanto, essa informação é ocultada 
pelas a trans a fim de proteger a masculinidade do marido ou namorado. Não obstante, ao passo que ela nega a possibilidade de um relacionamento estritamente passivo por parte das trans, admite que só penetra o companheiro por iniciativa dele, pois se dependesse do próprio desejo "era mais fazer com homem de fora, não com meu marido. Eu queria que só ele me penetrasse, só que ele se sente bem eu penetrando ele, então para ele não procurar outra travesti na rua, é bom eu mesmo penetrar!

Além do carinho, o sexo é para Karla um grande diferencial entre a mulher cis e a mulher trans. No que diz respeito a transexualidade, o sexo exercido como forma de trabalho na prostituição ou com seus companheiros, parece sobrepor a identificação indígena, este é um fator significativo para a formatação de sua experiência sexual. Nesse sentido, de acordo com as posições sexuais, caso sinta-se viril e penetradora, ela aciona um gênero masculino, quando passiva, fica evidente a característica do gênero feminino. No entanto, não partilho da concepção de "mobilidade de gênero" usada por Cecília Patrício (2002) para argumentar que as mulheres trans possuem uma identidade de gênero circular entre masculino e feminino, não havendo uma marcação delimitada entre um e outro. Nesse sentido, Fernanda Cardozo contra argumenta:

Dizer que não são femininas é negar-lhes um status pelo quais elas elaboram esforços diários, o que se configura altamente despolitizante, de outro lado, ao caracterizar as travestis como uma possibilidade de transito entre masculino e feminino, tal concepção corre o risco de cristalizar os lugares do gênero, de negar a ideia de performatividade e colar a identidade de gênero e sexualidade (Cardozo, 2007: 246).

Posto isso, sou levada a crer que Karla, em sua intensidade singular, experimenta o gênero no corpo materializado por meio do diálogo com características viris, passivas e femininas atravessada ela percepção geracional, pois deseja voltar a "ser homem" quando envelhecer. Assim, os relacionamentos afetivos entre homens, mulheres e outras trans são fundamentais para promover a circulação irrestrita do gênero em um corpo que gasta muito tempo e esforço para tornar-se cada fez mais feminino a fim de cumprir sua "sina".

\section{0 caminho inverso: da aldeia para Europa}

Fernanda Farias e Albuquerque, a Princesa, foi a primeira trans do interior paraibano, que se tem notícia, a migrar para Itália no fim da década de 80. De acordo, Luciana Ulgheri (2016: 209): "para uma transexual brasileira dos anos 
oitenta, não tendo, porém, nada na lei que a discriminasse diretamente em seu país, a escolha para emigrar para a Europa podia ser consequência de uma praxe cotidiana de discriminação e violência à margem da lei". Entre suas narrativas sobre a experiência de viver em São Paulo, Fernanda coloca:

Em Fevereiro de 1987 e alguns meses antes tinha sido formado o novo governo de Jânio Quadros. Com um projeto simples e linear: acabar com a criminalidade e com a prostituição. Desandaram a matar travestis e pivetes. Esquadrões da morte, grupos de moralistas e polícia. Todos se inflamaram, com respaldo do governo. Os muros foram cobertos com cartazes: "Limpe São Paulo matando um travesti por noite". As calçadas viraram campo de batalha (Albuquerque; Janelli, 1994: 100).

Para Princesa, sair da zona rural de Remígio, no brejo paraibano, migrar para Campina Grande, João Pessoa, Recife, Natal, Salvador, Rio de Janeiro, São Paulo e, por fim, para Madri na Espanha e várias cidade na Itália, fez parte de um projeto de fuga da violência estrutural, a transformação do corpo e de retorno para os laços familiares, especialmente, após conseguir dinheiro para comprar uma casa e montar um negócio que lhe desse a possibilidade de trabalhar e sustentar-se. Ir para Europa significava a fuga da agressividade da polícia e da sociedade, pois para Princesa, o desprezo social acompanha a invenção das trans. Na primeira metade dos anos 80, Fernanda era informada, pelas trans que retornavam à contragosto, que "na Europa a polícia não mata nas calçadas. Um paraíso" (Albuquerque; Janelli, 1994).

No fim da década de 80, Kelly era apenas uma criança. Não tinha noção do sofrimento que acompanhavam as pessoas trans nos grandes centros urbanos, pois a aldeia, mesmo considerada limitada em seus recursos econômicos, era um lugar que proporcionava segurança. Na aldeia, as trans pertencem ao um núcleo familiar em que todos se conhecem, isto é levado em consideração pelas demais pessoas. Como fez crer uma interlocutora: "aqui todo mundo tem uma família que merece respeito!".

As trans da aldeia, assim como demais pessoas, circulavam por espaços urbanos em busca de melhores condições econômicas, no entanto, no período que sucedeu esta pesquisa, Kelly, de pele morena, olhos escuros, cabelo curto, altura mediana, magra e muito receptiva morava sozinha em uma modesta casa na Aldeia Caeira, próxima à Baía da Traição e, passava o dia na casa da mãe. Pertence a uma família de 5 irmãos: "três homens e duas mulheres comigo!", contabiliza a si como mulher. $O$ pai deixou a família quando ela era criança, sua mãe 
casou-se novamente e, o padrasto é o único a não ter bom relacionamento com ela. Seus parentes a tratam bem e respeitam sua orientação sexual. Ela tem uma prima trans, casada com um homem indígena há mais de 10 anos.

As experimentações de sentimentos e sexos entre Kelly e os rapazes deu-se quando ainda era muito jovem, em torno dos 10 anos com garoto de idade semelhante. Ao lembrar-se de sua primeira relação sexual, ela não entrou em detalhes, mencionou apenas que "foi bem... Foi muita coisa não, mas foi bom... [risos] foi agradável”. Depois de sua primeira relação sexual com rapaz, deu-se início um processo de transformação corporal. Relata: "Começou logo gayzinha, e rapidamente comecei a virar travesti!" Ela diz não ter recebido ajuda e conselhos de trans mais velhas, argumenta que se transformou em mulher trans por "intuição". Ela sentiu que deveria empregar outra estética em seu corpo e assim o fez, como uma espécie de autodeterminação. Trocar bermudas por saias e usar maquiagens foram os primeiros passos intuitivos, no entanto, recebeu orientação de como fazer a aplicação de hormônio de suas amigas trans que moravam na cidade.

Os parentes têm um papel decisivo nas transformações dos corpos das trans, por causa dos familiares, muitas fogem de casa ou são expulsas quando decidem deixar o corpo feminino. Para Kelly, a avó teve um papel importante no início de sua transformação, foi a pessoa que a acolheu quando o relacionamento com o padrasto ficou insustentável. Aos 14 anos já se apresentava como "travesti" e, para continuar com as transformações corporais, Kelly mudou-se para casa da avó, depois para casa de um amigo e, em seguida foi morar sozinha em uma casa que estava desabitada, na mesma aldeia que reside a família. De acordo com Kelly, sua relação com os vizinhos sempre foi boa, eles a respeitam, apenas no âmbito escolar, com adolescentes vindos de outras localidades, que havia comentários e piadinhas desagradáveis, logo ignorados.

Nas migrações internacionais de mulheres trans, o agenciamento pode ser considerado uma forma incipiente de negociações morais entre elas. Na maioria das vezes, são outras trans que emprestam o dinheiro e articulam a participação da migrante no mercado do sexo europeu. A estas são dados os nomes de cafetinas e, por mais que o valor emprestado seja inflacionado, são pessoas tratadas, na maior parte das vezes, com respeito e agradecimento. Em muitas ocasiões, atribui-se ao dinheiro emprestado e a possibilidade de pagá-lo com trabalho na prostituição, a chance de mudar de vida e realizar sonhos. Por essa razão, Kelly disserta sobre viagem para Itália, não apenas como meio de ganhar dinheiro, mas como a realização de um sonho, ela desejava morar em outro país e conhecer culturas diferente da sua. 
Kelly conhecia mulheres trans de outras localidades da Paraíba, que moravam na Itália e que vinham visitar a família e passear na Baía da Traição durante o carnaval. Neste período as trans tinham grande visibilidade, elas andavam em grupo e destacavam-se nas ruas, becos praias e rios tomados por milhares de pessoas vindas de outras regiões, estados e países (Guerra, 2015). Como a maior idade recém completada, Kelly foi alertada por uma amiga trans que já morava e trabalhava no mercado do sexo europeu, que poderia “dar certo lá!". Em seguida, ela ajudou organizar os documentos, comprar a passagem e, em poucos dias, Kelly estava na Itália, diferente de sua prima trans, que na mesma época foi extraditada de Portugal. Kelly passou 3 anos morando na Europa.

De acordo com Cecília Patrício (2008), ao buscar trabalho em território europeu as trans têm duas intenções básicas: investir em si mesma (por meio de modificações corporais - aplicação de silicone, retirar o pomo-de-adão) e adquirir bens e contribuir com o rendimento da família no Brasil. Dadas essas observações, Michelle Agnoleti acrescenta:

A experiência de viajar e trabalhar na Itália se constitui como mais uma dessas marcas distintivas, que proveem e catalisam todos os recursos que as orientam na direção do prestígio, do reconhecimento, da ascensão social. A migração é o casulo em cujo interior se engendram transformações físicas e morais, que torna a jovem que toma hormônio escondido da família em europeia (Agnoleti, 2014: 44).

Ao explanar sobre os motivos que levam trans brasileiras a romper fronteiras e ir para Europa, Cecília Patrício considera que não é apenas o trabalho mais lucrativo e a fuga da violência no Brasil, mas uma questão de gênero, pois para autora "a identidade de brasileiras, a brasilidade, não impedem as pessoas de trabalharem em seu país, ou em outro que seja, apenas a formação educacional direciona qual o posto que se pode assumir, mas é condição de gênero que limita ou impede que se consiga trabalho." (Patrício, 2008: 135). Por sua vez, a Europa foi criada, no imaginário do colonizado, como um modelo civilizatório a ser alcançado, ou seja: qualidade de vida, liberdade, igualdade e fraternidade.

Sobre o sistema econômico monetário é importante perceber que historicamente o capitalismo foi considerado, de maneira equivocada, algo libertador e progressista. Como argumenta Silvia Federici, "o capitalismo criou formas de escravidão mais brutais e mais traiçoeiras, na medida em que implantou no corpo do proletariado divisões profundas que servem para intensificar e para ocultar a exploração" (Federici, 2017: 119). É válido salientar que a identidade sexual e de gênero (homem, mulher, trans, cis) não deve ser visto apenas como 
uma construção de processos culturais, mas relacionada às classes sociais. Kelly, faz parte de uma precária classe econômica, migrar era algo que poderia "dar certo", ou seja: realizar sonhos, ganhar dinheiro e transformar seu corpo com o uso de silicones, deixando-a com formas mais arredondadas e femininas. Portanto, migrar como um projeto de vida está, sobretudo, ligado à classe social e colocar o gênero como fator principal, pode levar a um equívoco histórico.

Sentada na calçada da casa que morava na aldeia, Kelly falava com saudade sobre a estadia na Itália e de suas idas às casas de show no centro de Roma. Era com alegria que lembrava dos homens, ela os considera bonitos e educados, diferente dos brasileiros. Para Kelly, circular entre as casas de shows fazia parte do lazer e rotina de trabalho, pois precisava passar a impressão de estreia e se colocar sempre como novidade no mercado do sexo. Ao problematizar a mobilidade, Patrício (2008: 137) diz que ela 'é também uma estratégia, um 'truque' das travestis para se manterem protegidas, pois, de acordo com o trabalho que muitas delas realizam -a prostituição- algumas se envolvem em situação de marginalidade e desenvolvem rivalidade com outras travestis, principalmente quando estão em trottoir". Assim, a calçada é um local de várias experiências, sejam elas amigáveis, negociáveis ou não, entretanto, a mobilidade enquanto truque vai além da proteção ao corpo, é uma eficaz maneira de se manter nova no trabalho como faz crer Kelly: "a maioria dos travestis faz assim... quando num tá ganhando em um canto, vai para outro canto pra vê se ganha, para desparecer mais. Porque quando chega novo é novidade, né?”.

Para Marcia Sprandel (2013), o papel da antropologia "é analisar a construção de categorias sociais em seus significados, a partir de circunstâncias históricas específicas e de relações de poder" (Sprandel, 2013: 24). Nesse sentido, argumento que ao tratar sobre mobilidades internacionais de mulheres trans, a "clandestinidade" é uma categoria útil para pensarmos a construção dos estilos de migração trans, fortemente marcado pela noção de estrangeiro da América, região do globo arquitetada pelo ideário de pobreza e considerada pornotrópica (McClintock, 2010).

As mulheres trans que cruzam as fronteiras de países tidos como desenvolvidos, parecem ter a prostituição como produto final do deslocamento. Assim, além de um estrangeiro não pertencente (Simmel, 2005), para a mulher trans é acrescentado outro elemento moral: o sexo pago. Não obstante, é válido perceber que muitas estrangeiras valem-se do imaginário sedutor de sexo e perigo atribuído aos seus corpos, como elemento distintivos, por vezes Kelly falava que se apresentava como a "indiazinha" vinda de terra distantes para saciar fantasias sexuais do europeu em busca de sexo como pessoas consideradas exóticas, 
portanto, ela não era apenas uma mulher trans latina de pele bronzeada, Kelly representava os povos nativos do Brasil, esta categoria, por vezes desprezada, no mercado do sexo ganhava novos valores de poder e conquista na Europa.

\section{Ramona Pink}

Ramona Pink, é uma mulher trans muito sorridente e receptiva. Reside na aldeia, da qual só se ausenta para ir à cidade fazer compras para família ou quando arruma algum trabalho de diarista em casa de família. Ramona tem mais de 30 anos, é magra, corpo e braços definidos por causa dos trabalhos braçais, pele morena com algumas manchas causada pelo sol, olhos castanhos, cabelo curto, voz fina, simpática e muito sonhadora, deseja se tornar modelo e desfilar pelo mundo. Nosso primeiro encontro deu-se durante desfiles de beleza gay na Aldeia Tramataia, 2011 e o segundo no Tubarão Casa Show, 2012, na Baía da Traição, para eleger a miss gay da cidade.

Durante os eventos fotografei Ramona Pink e as demais trans, na época não sabia a projeção que as fotos teriam para pesquisas futuras. Em 2014, passei a morar na Baía da Traição, encontramo-nos durante as festividades carnavalescas, falei que havia impresso as fotografias registradas durantes os desfiles e que gostaria de entregá-las. Ramona permitiu que eu fosse até sua casa para entregar as fotos, ao ensinar o caminho até sua casa, ela disse: "Sabe onde éo Rio do Gozo?" Eu moro perto... Na Aldeia Tracueira”. Por meio das fotografias pude estreitar os laços com ela e sua família.

Os dias de festejos transcorreram e na manhã chuvosa do dia 06 de Março de 2014, sob a garoa do céu escurecido, fui ao encontro de Ramona na aldeia do famoso Rio do Gozo, cartografado no mapa geográfico e turístico da região. Atravessei várias aldeias, passei por grandes subidas e descidas, caminhos estreitos, com enormes bancos de areia, nos quais o mototaxista teve que usar toda a sua habilidade para que a motocicleta não saísse do curso. No caminho era possível apreciar a beleza de grandes árvores e, para minha tristeza, grande parte da vegetação nativa estava desmatada para a plantação de cana-de-açúcar.

Ramona é sobrinha de Severo, um conhecido pintor das paisagens da região, artesão, cantor e dono de uma banda de forró. Ela morava a poucos metros de distância da sua residência, por essa razão, além do Rio do Gozo, o tio famoso também era referência para que pudesse localizá-la. Após a encontrar na casa do tio, caminhamos até a casa onde morava com a família. Era uma construção simples: baixa, com paredes de barro e chão de cimento grosso em algumas partes; a cozinha ficava do lado de fora e tinha apenas um forno à lenha e madeiras 
ao redor. O banheiro da família também ficava fora da casa e era de alvenaria, construído por meio de projeto público para a população indígena. Entramos na casa pela porta dos fundos e atravessamos um pequeno corredor até a sala, na qual Ramona deixava guardados os seus sapatos e sandálias de salto alto; ficamos por alguns instantes naquele local, minimamente ornamentado com algumas fotografias de familiares, jogadores de futebol e da própria travesti; havia também uma rede de dormir pendurada na parede em um torno de madeira. A sala ainda contava com um sofá, cadeira de balanço e um pequeno móvel que servia de apoio à televisão e ao aparelho de DVD.

Depois que conversamos e de explicar minha função de antropóloga, saímos para caminhar em direção ao Rio do Gozo e conhecer a aldeia. Ela apresentou $\mathrm{o}$ ateliê do tio e a casa da avó materna; todos moram próximos. Apresentou-me também o pai, que estava sentado debaixo de um pequeno coqueiro, mostrou o salão de festas da aldeia, onde era a casa do cacique e contou algumas histórias do Rio do Gozo que estava ligada as lembranças de infância e ao senhor mais velho do local.

A Aldeia Tracueira é atravessada pela Rio Sinimbu, a nascente fica a menos de $1 \mathrm{~km}$ da casa de Ramona, ela lembra que no percurso do rio foi criado um "pocinho" há cerca de 20 anos. Este pocinho atraiu pessoas de várias partes da região, diz a trans:

Vinha gente da Baía, vinha curtir, ficava com as meninas... As barreiras eram lisas e a gente ia bagunçar nas barreiras... Daí, pegaram um casal fazendo amor na barreira (risada). Perguntaram: por que vocês estão fazendo isso aqui? Agora, nós vamos botar esse nome mesmo no rio. Rio do Gozo... porque vocês vieram gozar aqui! Menina, foi uma resenha, visse? A menina ficou com vergonha, até hoje esse povo, ninguém mais viu eles! Ai, por Rio do Gozo ficou... aí tá em João Pessoa, na internet e em tudo que é canto, ficou Rio do Gozo...

Sobre a história da região, não é recente o fato dos rios estarem ligados às práticas sexuais. Em um texto épico que descreve a capitania da Paraíba, Elias Herckman (1886) narra a existência de um rio chamado Tibery, em cujas margens havia engenhos e também indígenas, os Pitiguares (hoje conhecido por Potiguara). Herckman afirma que a palavra tibero faz referência ao pecado sodomítico ocorrido nas proximidades dessas águas: quando os Potiguara se encontravam em uma situação de batalha com indígenas que habitavam as terras do sertão, capturaram o jovem guerreiro Tapyas e dele abusaram no Tiberoy, 
caracterizando a água do pecado sodomita (Herckman, 2010). Portanto, histórias envolvendo práticas sexuais nos rios do Litoral Norte, data de longo tempo.

Chegando ao rio, Ramona apontou para o lugar no qual o casal estava transando, ela disse que presenciou a cena, mas por ser criança, não entendia o que estava acontecendo. O lugar era considerado ótimo para se divertir, ela contou que certa vez, às duas horas da madrugada, mesmo com a água gelada, foi tomar banho acompanhada de sete rapazes, após beberem e divertirem-se os rapazes quiseram "avançar o sinal" com ela e, por essa razão, foi embora. Ao retornarmos do Rio do Gozo, um trecho do Rio Sinimbu, seguimos até a nascente. Ramona cumprimentava as pessoas e elas a cumprimentavam de volta. A minha primeira impressão foi de uma aparente tranquilidade dos aldeões com a presença de Ramona, no entanto, explicou-me que também havia tensões por parte de alguns aldeões, pois tinham preconceito com o seu modo de ser e que às vezes sentia vontade de viver fora da aldeia, de conseguir um emprego e ganhar mais dinheiro, posto que sua renda se resumia ao auxílio do Programa Bolsa Família" ${ }^{11}$, trabalhos domésticos e na roça.

O irmão mais novo de Ramona era um simpático e educado rapaz que adorava jogar futebol e, ao observar a relação deles por alguns momentos, era possível perceber que eles se davam bem, diferente da relação com o irmão mais velho, que por não concordar com a sexualidade da irmã, mantinha-se distante. Com o passar do tempo, surgiram outras descobertas sobre a vida cotidiana de minha simpática anfitriã. Em busca de comida, seguimos até o bar, restaurante e mercearia do Miguel Moela, - onde havia frequentes serestas e shows com pequenas bandas de forró, - mas antes de alcançarmos esse nosso destino a fim de almoçarmos, passamos pelo campo de futebol da aldeia, o que despertou lembranças do tempo em que Ramona era a goleira do time das meninas, elas saíam para outras aldeias e cidades. Sobre essas lembranças, Ramona recorda: "o que mais me alegrava era isso... Eu adorava pegar bola... e quando enchia de gente pra assistir o jogo... Vinha gente de fora, dizia: 'ai, vamos pra Tracueira, assistir o jogo das meninas e vê aquela bicha agarrando". Este tempo de "pegar bola” que Ramona narrava cessara, pois, as meninas com quem jogava se casaram, tornaram-se mães e o time de futebol chegou ao fim.

O restaurante de Miguel Moela estava fechado e retornamos para casa, por um percurso diferente: caminhamos até enormes pés de mangas que apesar do

11 "É um programa de transferência direta de renda, direcionado às famílias em situação de pobreza e de extrema pobreza em todo o País, de modo que consigam superar a situação de vulnerabilidade e pobreza”. Informações retirada do site da Caixa Econômica Federal. 
fim da safra, conseguimos catar alguns frutos. Depois entramos na casa de um simpático casal de idosos, com os quais conversamos na cozinha por um instante. Ramona demonstrava entrosamento com o casal, quando saímos da casa ela explicou que havia trabalhado para eles como doméstica, mas uma de suas filhas passou a morar com eles e ela perdeu o emprego.

Ir até a aldeia e entregar as fotografias para Ramona, a meu ver, seria um acontecimento pontual, todavia ela se mostrou muito agradecida pelo que chamou de "consideração": ter ido à sua casa e presenteado com algo de que ela gostava, coisa que ninguém havia feito, segundo ela. Um contato que eu imaginava ser apenas sutil, tornou-se mais frutífero do que qualquer roteiro de entrevista. Soube de suas histórias ao caminhar pelas veredas, dentro do mato e nas águas cristalinas do rio. Ramona tinha traços simples, costumava expressar o que sentia e quase sempre estava com sorriso incontido. Nesse sentido, ao transitar pela aldeia com a trans e ver que os espaços evocavam lembranças prontamente compartilhadas, fez de uma visita que parecia simples, extraordinária, pois além de saber das suas memórias relativas ao lazer, sociabilidade e o contato com a vizinhança, ainda pude conhecer parte de sua família: pai, irmão mais novo, tio artista e uma gentil avó.

Dias depois do nosso primeiro encontro Ramona e eu mantivemos contato e fomos juntas à Festa das solteirinhas na aldeia Santa Rita. "Ah... eu adoro festas, corro léguas por uma balada!", foi a primeira frase dita por Ramona Pink ao nos dirigirmos para o local. Em quase todas as aldeias há um espaço para os festejos. O salão de festa da aldeia dispunha de uma tenda de alvenaria, telhado de fibrocimento sustentado por vigas feitas de canos pvc, piso de cimento e com um palco ao fundo para apresentação das bandas convidadas. O cacique da Aldeia era responsável por cobrar o ingresso, no entanto, nesta festa as mulheres não pagavam para entrar, por essa razão, Ramona e eu tínhamos passagem livre. Ramona Pink reencontrou uma amiga e enquanto a banda não dava início à apresentação, fomos até sua casa, que ficava ao lado do evento.

Próximo a hora de voltarmos à tenda da festa, alguns rapazes bateram à porta e pediram água para a dona da casa, ocasião que Ramona Pink aproveitou para expressar seus desejos: "Hoje eu quero um boyzinho, viu?" Os rapazes agradeceram pela água e saíram sem nada falar, apenas cruzaram olhares. Durante o show, Ramona também estava na companhia da prima e de uma amiga, ela movimentava o corpo no ritmo de algumas músicas e ao ser chamada para dançar, logo recusou. Algumas vezes ela ficava parada ou dançava sozinha, após posicionar-me de longe, pude observar que ela circulava pelos espaços da festa, atraindo os olhares dos homens presentes. Por fim, no decorrer do tempo que 
ficamos juntas e às vezes que se seguiu depois da visita a sua casa, Ramona parecia apresentar uma característica reservada, pouco falava sobre seus relacionamentos e sempre ressaltava a responsabilidade que tinha com a família após o falecimento da mãe.

\section{Em busca de conclusão}

Pessoas como Karla, Kelly, Ramona Pink e outras que não se encaixam no emoldurado e encaniçado modelo heteronormativo são consideradas subalternas, (especialmente fora da região de origem), não apenas pela sexualidade destoante, mas por acionar identidades ligadas aos povos nativos e por residir em lugares considerados o cu do mundo. Por sua vez, o corpo é uma engenharia política e moral no qual o ânus, para além de uma zona erógena (Preciado, 2014), move as noções valorativas da moralidade e das prestações de serviços. Posto isso, é válido afirmar que os usos dados ao ânus, de forma grosseira, localizam e atribuem importância social ao indivíduo. Portanto, dificilmente saberemos como os Potiguara administram os papeis sexuais, tudo o que temos são indícios de uma realidade violentamente transformada com o intuito de purificação.

As noções de vulnerabilidade, submissão aos abusos de poder e clandestinidade são forma de construir com mais eficácia o migrante genérico, especialmente mulheres trans e cis vindas de regiões pobres do mundo. Nesse sentido, Adriana Piscitelli (2013) argumenta que "o problema é que as percepções sobre quem está nessa situação contrapõem as mulheres de regiões 'ricas', concebidas como emancipadas e independentes, com controle sobre seus rendimentos, corpos e sexualidades" (Piscitelli, 2013: 91). Assim, no que diz respeito à circulação internacional, os estudiosos não negam a presença da exploração de gênero. Não obstante, apontam para a possibilidade de pensar às estratégias relacionais no mercado do sexo, não apenas de forma estigmatizada, mas como uma questão emancipatória que produz economia política e agenciamentos, possibilitando que trabalhadoras do sexo adquiriram capital econômico e social. Assim, é necessário alargar as perspectivas teóricas sobre fronteiras, interseccionalidade e estratégias domésticas, pois as mulheres trans estão inseridas em um complexo jogo de cena das hierarquias territoriais e de sexualidade. Como bem expõe Luciana Ulgheri:

Se sexo, gênero, raça, sexualidade, são construtos culturais catalogados e hierarquizados, de modo a fazer uma distinção entre as corporeidades que merecem ou não reconhecimento político legal, os migrantes também passam pelo mesmo processo como corpo estranho e capaz de colocar em risco a coesão - língua, tradição etc. - do Estado-Nação (Ulgherim, 2016: 211). 
No cruzamento de fronteiras e circulações, dinheiro e gênero são conceitos fundamentais, sobretudo, entre as mulheres trans, pois impulsionam a migração em diferentes territórios, no qual circular é uma característica importante para a composição da pessoa trans enquanto processo relacional e de corporeidade (Patrício, 2008; Pelúcio, 2007). Além do mais, gênero nos mercados do sexo, é uma categoria complexa que não se limita as relações existentes entre homens e mulheres; masculinidades e feminilidades (Piscitelli, 2013). Ao que parece, uma característica marcante das trajetórias de vida das trans brasileiras é a forma como a mobilidade se apresenta e constitui uma parte significativa de suas vidas, em especial para aquelas que têm seus modos de subsistência vinculados ao trabalho na prostituição.

Ao refletir sobre a circulação, afetos e migração de mulheres trans em terras indígenas da Paraíba é fundamental destacar que as histórias das pessoas devem ser entendidas em seu mistério, compreendidas como mutáveis em função dos múltiplos encontros e arranjos que conferem sentido e lugar às existências pessoais. Nesses termos, este artigo não é um acumulado aleatório de trajetórias de vida, de biografias ou memórias, mas a possibilidade de notar que a característica de indianidade (Castro, 2011) acionadas pelas mulheres trans são forjadas entre lugares: aldeias, cidades pequenas, média, megalópoles e território estrangeiro. Por fim, são pessoas que trazem consigo a marca do gênero corporal e performativo da aldeia para Europa e vice-versa, que se modificaram em seus encontros, nos lugares onde estiveram e que ajudaram a transformar com sua presença e modo de estar no mundo.

\section{Referências}

A INDIANIDADE é um projeto de futuro, não uma memória do passado. Entrevista com Eduardo Viveiros de Castro. Prisma Jur., São Paulo, v. 10, n. 2, jul./dez. 2011, pp. 257-268. AGNOLETI, Michelle Barbosa. A transmigração no espaço, no corpo e na subjetividade: deslocamentos de fronteiras na experiência de travestis paraibanas na Itália. Tese de Doutorado, Sociologia, Universidade Federal da Paraíba, João Pessoa, 2014.

ALBUQUERQUE, Fernanda Farias de; JANNELLI, Maurizio. A Princesa: depoimentos de um travesti brasileiro a um líder das Brigadas Vermelhas. Rio de Janeiro, Nova Fronteira, 1994.

BUTLER, Judith. Problemas de Gênero: feminismo e subversão da identidade. Rio de Janeiro, Civilização Brasileira, 2003.

CARDOZO, Fernanda. Performatividades de gênero, performatividades de parentesco: notas de um estudo com travestis e suas famílias na cidade de Florianópolis/SC. In: 
GROSSI, Miriam; UZIEL, Anna Paula; MELLO, Luiz (Org.). Conjugalidades, parentalidades e identidades lésbicas, gays e travestis. Rio de Janeiro, Garamond, 2007, pp. 233-251.

FEDERICI, Silvia. Calibã e a bruxa: mulheres, corpo e acumulação primitiva. São Paulo, Elefante, 2017.

FERREIRA, Paulo Rogers. Os afectos mal-ditos: o indizivel nas sociedades camponesas. São Paulo, Hucitec/ANPOCS, 2008.

FOUCAULT, Michel. História da sexualidade: a vontade de saber. Rio de Janeiro, Graal, 1988.

GUERRA, Verônica Alcântara. "Diague, racha" - travestis entre zonas urbanas e indígenas: Litoral Norte da Paraíba, Monografia, Departamento de Ciências Sociais, Rio Tinto, 2012.

GUERRA, Verônica Alcântara. Espaços e sexualidades trans: lazer como arte da existência na Baía da Traição. Ponto Urbe, São Paulo, v. 21, Dezembro 2017, pp. 1-15.

GUERRA, Verônica Alcântara. "Sou salobra": travestilidade, lazer e sociabilidade no litoral norte da Paraíba. Dissertação de Mestrado, Antropologia Social, Universidade Federal da Paraíba, João Pessoa, 2015.

HERCKMAN, Elias. Descripção Geral da Capitania da Parahyba. Revista do Archeológico e Geográphico do Estado de Pernambuco. Recife, IAGP, 2010 [1886], pp-240-288.

MCCLINTOCK, Anne. Couro imperial: raça, gênero e sexualidade no embate colonial. Campinas, Editora da Unicamp, 2010.

PATRÍCIO, Maria Cecília. No truque: transnacionalidade e distinção entre travestis brasileiras. Tese de Doutorado em Antropologia Social, Universidade Federal de Pernambuco, Recife, 2008.

PELÚCIO, Larissa. Abjeção e desejo: uma etnografia travesti sobre o modelo preventivo de AIDS. São Paulo, Annablume-Fapesp, 2009.

. "Amores perros" - sexo, paixão e dinheiro na relação entre espanhóis e travestis brasileiras no mercado transnacional do sexo. In: PISCITELLI, Adriana; ASSIS, Glaúcia de Oliveira; OLIVAR, José Miguel Nieto. (Org.). Gênero, sexo, afetos e dinheiro: mobilidades transnacionais envolvendo o Brasil. Campinas, UNICAMP/ PAGU, 2011.

. Nos nervos, na carne, na pele: uma etnografia sobre prostituição travesti e o modelo preventivo de Aids. Tese de Doutorado, Ciências Sociais, Centro de Educação e Ciências Humanas, Universidade Federal de São Carlos, São Carlos, 2007.

PATRÍCIO, Maria Cecília. No truque: transnacionalidade e distinção entre travestis brasileiras. Tese de Doutorado, Antropologia, UFPE, 2008.

PERLONGHER, Néstor. O Negócio do michê: a prostituição viril em São Paulo. São Paulo, Fundação Perseu Abramo, 2008. 
PISCITELLI, Adriana. Trânsitos: brasileiras nos mercados transnacionais do sexo. Rio de Janeiro, Ed Eduerj, 2013.

PRECIADO, Beatriz. Manifesto contrassexual: práticas subversivas de identidade sexual. São Paulo, n. 1 ed., 2014.

SIMMEL, Georg. Questões fundamentais da sociologia: indivíduo e sociedades. Rio de Janeiro, Jorge Zahar, 2005.

SPRANDEL, Marcia. Algumas observações sobre fronteiras e migrações. Ciência e Cultura. São Paulo, v. 61, n. 1, 2013, pp. 24-26.

ULGHERI, Luciana Miranda Marchini. Princesa: natura, cultura, acaso e liberdade. Tese de Doutorado, Literatura comparada, USP, 2016.

Recebido em: 03/02/2020

Aprovado em: 20/03/2020

\section{Como citar este artigo:}

GUERRA, Verônica Alcântara. Circulação, afetos e migração: notas para uma análise antropológica de mulheres trans em terras indígenas da Paraíba. Contemporânea Revista de Sociologia da UFSCar, v. 10, n. 1, jan.- abril 2020, pp. 101-123. 
